\title{
INFORMAL SECTOR - A SURVIVAL OR CONSOLIDATION LIVELIHOOD STRATEGY: A CASE STUDY OF THE INFORMAL SECTOR ENTREPRENEURS IN PALEMBANG CITY, INDONESIA
}

\author{
Armansyah* \\ Student of Doctoral Program in Population Science, Gadjah Mada University \& \\ Lecturer in Geography Education, PGRI University of Palembang, Indonesia \\ Sukamdi, Pitoyo Agus Joko, Lecturers \\ Faculty of Geography, University of Gadjah Mada, Indonesia \\ *E-mail: armansyah@mail.ugm.ac.id
}

\section{ABSTRACT}

The informal sector is inseparable from the population of Indonesia. Since the 1998 crisis, it has been the source of life for many people. Moreover, in the current era of demographic dividend, it becomes, albeit subsistent, the most popular survival livelihood strategy. This study aimed (1) to investigate and elaborate whether or not the informal sector was included in the survival or consolidation livelihood strategy and (2) to describe how this sector potentially transitioned from the survival livelihood strategy into the consolidation one. This quantitative research used surveys to collect data from 302 respondents. The results showed that the informal sector tended to be considered as the survival livelihood strategy, in that it was thought to accommodate all limitations of informal sector entrepreneurs, such as lack of skills, investment, and work standards, use of only simple technology, low access to banking and social services, and little to no interrelation with other sectors. Since only two of ten indicators of transition were met, namely education and income, the potential of informal sector for transforming from survival to consolidation livelihood strategy was categorically low and, thereby, classified as Rank 4.
\end{abstract}

\section{KEY WORDS}

Informal sector, livelihood strategy, survival, consolidation.

One of the economic development goals is to meet the basic needs of the population of a country through increased income (Patta, 2019). Individuals or groups have implemented many strategies to fulfill their needs. Based on the household socioeconomic status, livelihood strategies can be differentiated into three, namely survival, consolidation, and accumulation (White, 1991 in Wijayanti, Baiquni, \& Harini, 2016). According to Susanto \& Sudrajat (2017), a strategy is a sustainable action performed by an individual or group, aiming to achieve specific necessities. Meanwhile, livelihood strategy is an effort selected by an individual or group to live their life based on their assets, access, activities, and capacities (Baiquni, 2007). With this strategy, people seek to fulfill their basic needs, such as food, clothing, and shelter. A community that still encounters problems in these basic needs is commonly regarded as lower class or poor (Fatimah, 2013).

The informal sector is an unregistered economic activity outside government regulations (Hart, 1973) that is ubiquitous in developing countries, including Indonesia. In the era of demographic dividend, this sector becomes the most rational alternative employment due to its capability to accommodate millions of people who cannot work in the formal industry as the result of their lack of education and skills (Lamba, 2011). Also, the typically large numbers of the economically productive population in Indonesia during this era poses various complex labor issues like limited employment and the massive influx of foreign workers that continue to fill both low-skilled and professional positions.

In such conditions, the government is expected to be more involved in the informal sector. Despite being marginalized, this sector can be independent and survive in any 
circumstances (Pitoyo, 1999). Mani (2017) suggests that a culture-based communication approach is necessary for combining all elements of population - including the government, workers' associations, the community, and groups of workers - and incorporate them into urban street vendor relocation policy, in particular, and policies on informal sector workers, in general. Policies on eradicating the informal-sector activities (Smart \& Smart, 2017) or evictions surely can be enacted; however, it does not eliminate the possibility of informal workers to re-start the same activities elsewhere (Rukmana, 2009 in Chirisa, 2014).

The informal sector is commonly considered as a livelihood strategy because it offers manageable resources to fulfill the basic needs (Susanto \& Sudrajat, 2017). Its elements are capabilities, activities, and assets (Chambers \& Conway, 1992 in Saleh, 2014), including the accumulation of private or family assets (Abdurahhim, Sunito, Dharmawan, \& Sudiana, 2014). In the next stage, asset ownership is considered by the low-income population to build a livelihood strategy and leave the cycle of poverty (Pitoyo \& Alfana, 2015). In this paper, the elements are modified into parameters indicating the potential of the informal sector to transition from a survival livelihood strategy into a consolidation one. The presented study sought to explore all data and information to prove such potential.

\section{METHODS OF RESEARCH}

This quantitative research was intended to find out a generalization with predictive values (Sugiyono, 2016). The indicators used to identify the transition of livelihood strategy comprised three aspects, i.e., assets, access, and activities, which were modified by providing each of them with a description. For further details, the indicators of the livelihood strategy transition are presented in Table 1 below.

Table 1 - Indicators of Livelihood Strategy Transition

\begin{tabular}{ccc}
\hline No & Indicators & Items \\
\hline 1 & Assets & Skills, technology, income, and education \\
2 & Access & Access to banking and social services, and interrelation with other sectors \\
3 & Activities & Supply management ability, work standards, and investment \\
\hline
\end{tabular}

Source: Modified from White (1991 in Wijayanti et al., 2016).

In the initial stage, the data were collected by surveys and further analyzed using frequency (descriptive) statistics. Subsequently, the data frequency was scored, with the principles shown in Table 2 below.

Table 2 - Scoring Rubrics

\begin{tabular}{|c|c|c|c|c|}
\hline No & Indicators & Items & Scores & Ranks \\
\hline \multirow{4}{*}{1} & \multirow{4}{*}{ Assets } & Skills & 1 & \multirow{11}{*}{$\begin{array}{c}\text { Rank } 1 \text { (very potential) }=\text { higher than } 8 \\
\text { Rank } 2 \text { (potential) }=6-8 \\
\text { Rank } 3 \text { (fairly potential) }=3-5 \\
\text { Rank } 4 \text { (less potential) }=0-2\end{array}$} \\
\hline & & Technology & 1 & \\
\hline & & Income & 1 & \\
\hline & & Education & 1 & \\
\hline \multirow{3}{*}{2} & \multirow{3}{*}{ Access } & Access to banking service & 1 & \\
\hline & & Interrelation between sectors & 1 & \\
\hline & & Access to social services & 1 & \\
\hline \multirow{4}{*}{3} & \multirow{3}{*}{ Activities } & Supply management ability & 1 & \\
\hline & & Work standards & 1 & \\
\hline & & Investment & 1 & \\
\hline & Total & & 10 & \\
\hline
\end{tabular}

Source: Data analysis, 2019.

The population in this study was 1,498 informal sector entrepreneurs in Palembang City, and 302 of them were sampled based on the Krejcie and Morgan's Table (Pitoyo, Eddy, Pande, \& Sumini, 2017). The research data were collected through a survey, documentation, and observation, and then processed using descriptive analysis, that is, frequency statistics, and scoring. Finally, these data were interpreted and depicted in tables, descriptions, and theoretical dialogue of previous relevant studies. 


\section{RESULTS AND DISCUSSION}

This study was designed to figure out empirical evidence that the informal sector had the potential to transition from a survival livelihood strategy into a consolidation one. As elaborated in Introduction, livelihood strategy is a choice shaped by personal or family assets, access, activities, and capabilities (Alviawati, 2013). Also, the adopted theoretical background is the theory of evolution, which states that the informal sector has the potential to accumulate resources and, therefore, can transition just like the formal sector at a specific time (Hosier, 1987). This section is divided into three parts: 1) Informal Sector as a Survival Livelihood Strategy, 2) Informal Sector as a Consolidation Livelihood Strategy, and 3). The Potential of Informal Sector to Transition from Survival into Consolidation Livelihood Strategy.

Informal Sector as a Survival Livelihood Strategy. During a crisis, the informal sector appears as the survival livelihood strategy undertaken by layoff victims and unemployed persons because it enables them to create opportunities to earn incomes (Brata, 2010). The informal sector is also resilient to any circumstances and can dominate the market share (Bairagya, 2013).

The indicators used to assess the survival livelihood strategy in this study are related to livelihood aspects on a household scale, namely access and capabilities, assets, and activities. 1) Access is the ability to make use of resources, including labor and technological capital, while capabilities are trained skills obtained from a series of training or life experiences. 2) Assets are associated with access to control over both tangible and intangible assets. Tangible assets are, among others, land, machinery, equipment, savings, and labor, whereas intangible assets include knowledge, skills, and relationships. 3) Activities are a set of attempts to self-transform from unsafe conditions by benefiting from assets and optimizing abilities possessed.

The informal sector entrepreneurs are currently perceived as yet having the three aspects mentioned above. Moreover, in most developing countries, the majority of the lowincome population employed informally (Chen \& Vanek, 2013). Besides, the informal sector appeared to be the survival livelihood strategy for layoff victims or bankrupt entrepreneurs during the 1997/1998 economic crisis (Mishra, 2010). Based on the literature review, there are several arguments as to why the informal sector is regarded as a survival livelihood strategy, as presented in detail in Table 3 below.

Table 3 - Similarities in the Characteristics of Informal Sector and Survival Livelihood Strategy

\begin{tabular}{ccc}
\hline No & Indicators & Similar Characteristics \\
\hline 1 & Nature of Business & Easily changed, less organized, and irregular \\
2 & Target Market & Lower-middle class, and for basic needs \\
3 & Access & Limited \\
4 & Technology & Basic \\
\hline
\end{tabular}

Source: Modified from the Characteristics of Informal Sector (Hidayat, 1998) and the Survival Characteristics of Livelihood Strategy, delivered in the Lecture on Poverty and Unemployment Studies by Dr. Sri Rum Giyarsih, M.Si (2018).

Based on Table 3 above, the similarities between the informal sector and the survival livelihood strategy lie in four aspects, namely the nature of the business, target market, access, and technology. Ritonga \& Sari (2015) explain that the informal sector in Medan owns relatively poor access to banking with only $48.48 \%$ of informal sector entrepreneurs have access. These four aspects are assumed to contribute to the categorization of informal sector as a form of survival livelihood strategy.

Limited area/land in survival livelihood strategy is interpreted as a relatively insignificant capital in the informal sector. In this context, capital refers to not only land but many other assets like money, human resources, and relationships. Therefore, the ownership of narrow land, in this case, can be considered one of the relatively insignificant capitals in the informal sector. The common properties of the informal sector - i.e., it does not require higher 
education, skills, and experiences - emerge to be the main argument as to why odd jobs become the most dominant informal activities.

As a summary, the informal sector is regarded as a survival livelihood strategy due to the shared similarities between them. The informal sector provides a survival mechanism during crises (Mishra, 2010). The informal sector can accommodate various limitations owned by an individual or group that relies on survival livelihood strategies. It is inseparable from the nature of the informal sector, that is, flexible in terms of time and characteristics of labor characteristics (Soebyakto \& Armansyah, 2016).

Informal Sector as a Consolidation Livelihood Strategy. Table 4 describes three characteristics of a consolidation livelihood strategy, one of which seemingly has similarities with the informal sector, namely No. 3. This point contains the strength of social network and status that enables individuals or groups to step forward to the next strategy.

Table 4 - The Characteristics of a Consolidation Livelihood Strategy

\begin{tabular}{ccl}
\hline $\begin{array}{c}\text { Livelihood } \\
\text { Strategy }\end{array}$ & No & \multicolumn{1}{c}{ Characteristics } \\
\hline Consolidation & 1 & The household owns motorcycles, radio, and television. \\
& 2 & $\begin{array}{l}\text { The household has developed and consolidated by utilizing resources for mid-term and } \\
\text { long-term goals. }\end{array}$ \\
& 3 & The strength of social networks and status possibly leads to the next strategy. \\
\hline
\end{tabular}

Source: The Characteristics of Consolidation Livelihood Strategy, delivered in the Lecture on Poverty and Unemployment Studies by Dr. Sri Rum Giyarsih, M.Si (2018).

These characteristics are deemed identical to those of the informal sector, i.e., the capital comes from personal assets, family, colleagues, or informal institutions (Hidayat, 1998; Lamba, 2011). In other terms, social network means family, colleagues, or private/informal institutions. The more extensive the social network that the informal sector entrepreneurs have grown, the more capable they are to develop the strategy used.

Table 5 - The Potential (\%) of the Informal Sector to Transition from Survival into Consolidation Livelihood Strategy by Indicators

\begin{tabular}{|c|c|c|c|c|c|}
\hline No & Indicators & Items & Categories & $\mathrm{F}$ & $\%$ \\
\hline \multirow{8}{*}{1} & \multirow{8}{*}{ Assets } & \multirow[b]{2}{*}{ Skills } & No & 196 & 64.9 \\
\hline & & & Yes & 106 & 35.1 \\
\hline & & \multirow{2}{*}{ Technology } & No/Basic & 272 & 90.1 \\
\hline & & & Yes/Advanced & 30 & 9.9 \\
\hline & & \multirow{2}{*}{ Income } & $<$ IDR 3,000,000 & 70 & 23.2 \\
\hline & & & $>$ IDR $3,000,000$ & 232 & 76.8 \\
\hline & & \multirow{2}{*}{ Education } & $<$ Junior High School & 126 & 41.7 \\
\hline & & & $>$ Senior High School & 176 & 58.3 \\
\hline \multirow{6}{*}{2} & \multirow{6}{*}{ Access } & \multirow{2}{*}{ Access to banking services } & No & 272 & 90.1 \\
\hline & & & Yes & 30 & 9.9 \\
\hline & & \multirow{2}{*}{ Interrelation with other sectors } & No & 280 & 92.7 \\
\hline & & & Yes & 22 & 7.3 \\
\hline & & \multirow{2}{*}{ Access to social services } & No & 188 & 62.3 \\
\hline & & & Yes & 114 & 37.7 \\
\hline \multirow{6}{*}{3} & \multirow{6}{*}{ Activities } & \multirow{2}{*}{ Supply management ability } & No & 226 & 74.8 \\
\hline & & & Yes & 76 & 25.2 \\
\hline & & \multirow{2}{*}{ Work standards } & No & 292 & 96.7 \\
\hline & & & Yes & 10 & 3.3 \\
\hline & & \multirow{2}{*}{ Investment } & No & 216 & 71.5 \\
\hline & & & Yes & 86 & 28.5 \\
\hline
\end{tabular}

Source: Data Analysis, 2019.

Another reason underlying the argument that qualifies the informal sector as a consolidation livelihood strategy comes from the evolution theory. According to the evolution theory, the informal sector can develop and accumulate capital until it transforms into the formal sector (Hosier, 1987). Besides, developmentalism asserts that the informal sector has 
the same ability to develop as the formal sector and even provides greater prospects of increased income (Sethuraman, 1977; Hosier, 1987; Portes et al., 1989 in Pitoyo, 1999; Armansyah \& Aryaningrum, 2017). This perception indicates that the informal sector widely opens a window of opportunity for entrepreneurs to earn higher incomes and establish new enterprises without being constrained by government regulations (Mishra, 2010).

The Potential of Informal Sector to Transition from Survival into Consolidation Livelihood Strategy. The indicators used to assess the potential for transition were assets, access, and activities, each of which is elaborated in this section according to the predefined items. Table 5 below describes the items and indicators in question.

Kasali (2018) suggests that disruption has transformed the old ways into new ways through technology. This condition makes several industries reduce their number of workers and inevitably force them to turn to alternative jobs in the informal sector. In the past, the informal sector was mainly occupied by low-skilled workers. However, nowadays, high-skilled or educated workers tend to choose the informal sector, specifically entrepreneur-based occupations.

As presented in Table 5 , more than half $(58.3 \%)$ of the informal sector entrepreneurs had a higher education background (Senior High School and above), and most of them $(76.8 \%)$ earned a monthly income of at least IDR 3,000,000. Based on education and income, the informal sector entrepreneurs are assumed to own sufficient assets. This finding corresponds to Armansyah \& Aryaningrum (2017), in which several informal sector entrepreneurs have higher incomes than those engaged in the formal sector. It also supports the evolution theory that emphasizes the ability of the informal sector to grow into a formal one (Hosier, 1987) and to accumulate capitals (Muyambiri \& Odhiambo, 2018). However, the majority of the informal sector entrepreneurs did not have specific skills $(64.8 \%)$ nor use advanced technology in running their businesses (90.1\%), indicating the low potential of the informal sector to transform from survival to consolidation livelihood strategy.

In terms of access, a large proportion of the informal sector entrepreneurs in Palembang City (92.7\%) did not have interrelation with other sectors. It means that they tend to run their business personally and solely aim to fulfill their basic needs and the needs of the lower-middle class. Also, the majority of them had poor access to banking (90.1\%) and social services $(62.3 \%)$.

Based on activities, the informal sector entrepreneurs tend to develop a disposable economic system. Around $74.8 \%$ of them did not prioritize replacing their supplies before distribution or marketing. Also, a large share of them (96.7\%) did not have adequate work standards nor good investment (71.5\%).

Overall, the potential of the informal sector to transform from survival to consolidation livelihood strategies is considerably low, mainly because only two out of ten indicators are met.

Table 6 - The Scores of Potential of Transition from Survival into Consolidation Livelihood Strategy

\begin{tabular}{ccc}
\hline No & Indicators & Scores \\
\hline 1 & Skills & 0 \\
2 & Technology & 0 \\
3 & Income & 1 \\
4 & Education & 1 \\
5 & Access to banking service & 0 \\
6 & Interrelation with other sectors & 0 \\
7 & Access to social service & 0 \\
8 & Supply management ability & 0 \\
9 & Work standards & 0 \\
10 & Investment & 0 \\
\hline
\end{tabular}

Source: Data Analysis, 2019.

With only two scores, the potential of the informal sector to advance from survival to consolidation livelihood strategy was classified into Rank 4. It signifies a low potential 
because only two out of ten indicators are met, namely education and income. Todaro \& Smith (2011) argue that several informal sector entrepreneurs with decent incomes can eventually reach and outstrip the nature of the formal sector. Interestingly, this study confirmed that despite higher education, the informal sector entrepreneurs had low skills, limited access to banking, and basic or simple technology. This finding contradicts the consensus that a higher education likely leads to better skills, knowledge, use of technology, and access to banking services. The same case applies to income, which exceeded the regional (the City of Palembang) and provincial (South Sumatra) minimum wages but was associated with poor access to social services and low capacity to supply the raw materials and invest. It does not meet the expectation that the informal sector can transition into a better type of occupation, as in the case of SMEs, from micro, small, to middle-sized (Sabirin, 2016).

\section{CONCLUSION}

The potential of the informal sector in the City of Palembang to transition from survival into consolidation livelihood strategy is low because only two out of ten indicators of transition potential are met, i.e., education and income. Although the informal sector entrepreneurs have relatively high educational attainment, they still lack skills, use basic technology, and have minimum access to banking service. It contradicts the consensus that a higher education supposedly creates better skills and access to banking services and uses advanced technology.

In this study, a higher income does not necessarily enable the informal sector entrepreneurs to supply more goods, invest, and have better access to social services. This condition prevents the informal sector from transitioning into a consolidation livelihood strategy. To improve the potential for transition, the informal sector entrepreneurs must be able to disrupt themselves and their business through knowledge, skills, and technology that is relevant to the fourth (4.0) industrial revolution. In conclusion, the evolution theory and developmentalism have yet to apply to the informal sector entrepreneurs in Palembang City since the transition potential places the fourth rank (less potential).

Practically, this study provides several suggestions. 1) In the disruption era, the informal sector entrepreneurs have to be more creative in utilizing technology to reach a broader target market. They also have to create a stable community or association as the melting pot in which they can share insight, knowledge, and experiences, given that today is the era of sharing economy. 2) The government expectedly strives to eliminate opposition to the informal sector and place them as a part of the economic development of the formal industry.

\section{REFERENCES}

1. Abdurahhim, A. Y., Sunito, S., Dharmawan, A. H., \& Sudiana, I. M. (2014). Kerentanan Ekologi dan Strategi Penghidupan Pertanian Masyarakat Desa Persawahan Tadah Hujan di Pantura Indramayu. Jurnal Kependudukan Indonesia, 9(1). Retrieved from https://www.researchgate.net/publication/289520321_kerentanan_ekologi_dan_strategi_ penghidupan_pertanian_masyarakat_desa_persawahan_tadah_hujan_di_pantura_indra mayu_ecological_vulnerability_and_strategies_of_agricultural_livelihoods_in_rainfed_pa ddy_v

2. Alviawati, E. (2013). Strategi Penghidupan Rumah Tangga Peternak Sapi Perah di Desa Kepuharjo Kecamatan Cangkringan Pra dan Pasca Erupsi Merapi 2010. Majalah Geografi Indonesia, 27(2), 104-117. https://doi.org/10.22146/mgi.5276

3. Armansyah, \& Aryaningrum, K. (2017). Analisis Karakteristik Demografi Pekerja Wanita Sektor Informal pada Era Masyarakat Ekonomi ASEAN di Kota Palembang. Populasi, 25(1), 52-63. Retrieved from https://jurnal.ugm.ac.id/populasi/article/view/32415/19530

4. Bairagya, I. (2013). Sub-Contracting and Efficiency of The Informal Sector in India. The Journal of Developing Areas, 47(2), 341-361. Retrieved from 
http://www.jstor.org/stable/23612296

5. Brata, A. G. (2010). Vulnerability of Urban Informal Sector: Street Vendor in Yogyakarta, Indonesia. Theoretical and Empirical Researches in Urban Management, 5(5), 47-58. https://doi.org/10.5379/urbani-izziv-en-2010-21-02-006

6. Chirisa, I. (2014). The Role of the Informal Sector in African Regional Integration: Scope and Limits. Insight on Africa, 6(2), 131-144. https://doi.org/10.1177/0975087814535425

7. Fatimah, N. (2013). Strategi Bertahan Hidup Masyarakat Desa Rap Rap. Jurnal Masyarakat \& Budaya, 15(2), 235-258. Retrieved from http://jmb.lipi.go.id/index.php/jmb/article/download/39/22

8. Hart, K. (1973). Informal Income Opportunities and Urban Employment in Ghana. Source: The Journal of Modern African Studies, 11(1), 61-89. Retrieved from http://www.jstor.org/stable/159873

9. Hosier, R. H. (1987). The Informal Sector in Kenya: Spatial Variation and Development Alternatives. Source: The Journal of Developing Areas The Journal of Developing Areas, 21(21), 383-402. Retrieved from http://www.jstor.org/stable/4191591

10. Kasali, R. 2018. Disruption. Jakarta: PT Gramedia Pustaka Utama.

11. Lamba, A. (2011). Kondisi Sektor Informal Perkotaan dalam Perekonomian JayapuraPapua. Jurnal Ekonomi Bisnis, 16(2), 155-161.

12. Mishra, S. C. (2010). Keterbatasan Pembuatan Kebijakan Ekonomi Informal di Indonesia Pelajaran Dekade Ini. Jakarta: Organisasi Perburuhan Internasional.

13. Muyambiri, B., \& Odhiambo, N. M. (2018). The impact of financial development on investment: A review of international literature. Organizations and Markets in Emerging Economies, 9(2), 167-192. https://doi.org/10.15388/omee.2018.10.00009

14. Patta, T. (2019). Analysis of Income Growth and Evaluation of Economic Development in Central Sulawesi, Indonesia. RJOAS, 8(92). https://doi.org/10.18551/rjoas.2019-08.28

15. Pitoyo, A. J. (1999). Pedagang Kaki Lima pada Masa Krisis. Populasi, 10(2). Retrieved from https://jurnal.ugm.ac.id/populasi/article/view/12485/9037

16. Pitoyo, A. J., \& Alfana, M. A. F. (2015). Strategi Rumah Tangga Miskin Perdesaan Keluar Dari Kemiskinan: Kasus Tiga Desa Di Kulon Progo, Daerah Istimewa Yogyakarta. Populasi, 23(2), 55-70. https://doi.org/10.22146/jp.15695

17. Pitoyo, A. J., Eddy, K., Pande, M. K., \& Sumini. (2017). Manajemen Survei Kontemporer (1st ed.). Yogyakarta: Indie Book Corner.

18. Sabirin. (2016). Menilik Usaha Mikro Kecil Menengah (UMKM) Kesiapan Indonesia menghadapi Masyarakat Ekonomi Asean (MEA). Jurnal Kewirausahaan Dan Usaha Kecil Menengah, 1(2). Retrieved from http://stiesurakarta.id/index.php/jkukm/article/view/70

19. Saleh, S. E. (2014). Strategi Penghidupan Penduduk Sekitar Danau Limboto Provinsi Gorontalo. In Universitas Negeri Gorontalo. Retrieved from http://repository.ung.ac.id/get/simlit/2/996/1/Strategi-Penghidupan-Penduduk-Sekitar-

Danau-Limboto-Provinsi-Gorontalo.pdf

20. Smart, A., \& Smart, J. (2017). Formalization as confinement in colonial Hong Kong. International Sociology, 32(4), 437-453. https://doi.org/10.1177/0268580917701603

21. Soebyakto, B. B., \& Armansyah. (2016). Migrant Women Working at Informal Sectors: Empirical Study in Kuto Batu Village , Ilir Timur li Palembang City. International Journal of Humanities and Social Science, 6(4), 125-137.

22. Sugiyono. (2016). Metode Penelitian Kombinasi (Mixed Methods) (8th ed.; E. Sutopo, ed.). Bandung: Alfabeta.

23. Susanto, M., \& Sudrajat, S. (2017). Strategi Penghidupan Rumah Tangga Petani Di Desa Pandansari, Kecamatan Paguyangan, Kabupaten Brebes. Jurnal Bumi Indonesia, 6(4). Retrieved from http://lib.geo.ugm.ac.id/ojs/index.php/jbi/article/view/913/885

24. Todaro, M. P., \& Smith, S. C. (2011). Pembangunan Ekonomi (11th ed.; A. N. I. S. Maulana, ed.). Indonesia: Erlangga.

25. Wijayanti, R., Baiquni, M., \& Harini, R. (2016). Strategi Penghidupan Berkelanjutan Masyarakat Berbasis Aset di Sub DAS Pusur, DAS Bengawan Solo. Jurnal Wilayah Dan Lingkungan, 4(2), 133. https://doi.org/10.14710/jwl.4.2.133-152 